\title{
CRISE DO REGIONALISMO SUL-AMERICANO: DISCUSSÕES SOBRE INTEGRAÇÃO, FRAGMENTAÇÃO E DESINTEGRAÇÃO
}

\author{
Patrícia Nasser de Carvalho ${ }^{1}$ \\ Elói Martins Senhoras²
}

\begin{abstract}
0 regionalismo é considerado um dos fenômenos mais relevantes nas relações internacionais a partir de meados do século XX, apesar de ter passado por crescentes questionamentos e eventuais crises nas primeiras décadas do século XXI. Fundamentado em um procedimento metodológico de revisão bibliográfica e documental, no levantamento de dados e por análise gráfica e hermenêutica internacionalista, com base em economia política internacional e relações internacionais e na interpretação de dados, este artigo tem o objetivo de discutir as causas da crise dos esquemas regionais sul-americanos a partir da década de 2010. Com base nos resultados obtidos no texto, conclui-se que os diferentes esquemas regionais da União de Nações Sul-Americanas (Unasul), da Aliança Bolivariana para os Povos da Nossa América (Alba), do Mercado Comum do Sul (Mercosul) e da Comunidade Andina de Nações (CAN), assim como compartilham similitudes político-ideológicas conjunturais na conformação de projetos regionais de segunda e terceira "ondas", compartilham algumas convergências conjunturais e estruturais para explicar os contextos de crise do regionalismo sul-americano, apesar de as tendências de fragmentação e desintegração serem dispares entre os blocos.
\end{abstract}

Palavras-chave: América do Sul; Alba; CAN; Mercosul; Unasul.

\section{CRISIS OF SOUTH AMERICAN REGIONALISM: DISCUSSIONS ON INTEGRATION, FRAGMENTATION AND DISINTEGRATION}

Regionalism is considered one of the most relevant phenomena in international relations since the mid-twentieth century despite having gone through increasing questioning and occasional crises in the first decades of the 21st century. Based on a methodological procedure of bibliographic and documental review, data gathering, and a graphic and hermeneutic internationalist analysis based on data interpretation from the areas of international political economy and international relations, this article aims to discuss the causes of the crisis in South American regional schemes throughout the 2010s. Based on the results obtained in the article, it is concluded that the different regional schemes such as Union of South American Nations (UNASUR), Bolivarian Alliance for the Peoples of Our America (ALBA), Southern Common Market (MERCOSUR), and Andean Community of Nations (CAN) share political and ideological similarities in the shaping of regional projects of second and third "waves", as well as conjuncture and structural convergences to explain the crisis contexts of South American regionalism, despite the fact that the trends of fragmentation and disintegration are disparate among the blocs.

Keywords: ALBA; CAN; MERCOSUR; South America; UNASUR.

1. Professora na Faculdade de Ciências Econômicas da Universidade Federal de Minas Gerais (UFMG); economista; mestre em relações internacionais; e doutora em economia política internacional.E-mail:<patricia.nasser.carvalho@gmail.com>. Orcid: <https://orcid.org/0000-0002-8152-9779>.

2. Professor de graduação e pós-graduação stricto e lato sensu na Universidade Federal de Roraima (UFRR); economista e cientista político; e especialista, mestre e doutor em ciências. E-mail: <eloisenhoras@gmail.com>. Orcid: <https://orcid.org/0000-0002-4202-3855>. 


\title{
CRISIS DEL REGIONALISMO SUDAMERICANO: DEBATES SOBRE LA INTEGRACIÓN, LA FRAGMENTACIÓN Y LA DESINTEGRACIÓN
}

\begin{abstract}
Se considera el regionalismo uno de los fenómenos más relevantes en las relaciones internacionales desde mediados del siglo XX, a pesar de haber sufrido crecientes cuestionamientos y posibles crisis en las primeras décadas del siglo XXI. Basado en un procedimiento metodológico de revisión bibliográfica y documental, en la recopilación de datos y en un análisis gráfico y hermenéutico internacionalista basado en la economía política internacional y las relaciones internacionales y, en la interpretación de datos, este artículo tiene como objetivo discutir las causas de la crisis de los esquemas regionales en Sudamérica a lo largo de de la década de 2010. Con base en los resultados obtenidos, se concluye que los diferentes esquemas regionales de Unión de Naciones Suramericanas (Unasur), Alianza Bolivariana para los Pueblos de Nuestra América (Alba), Mercado Común del Sur (Mercosur) y Comunidad Andina de Naciones (CAN), así como comparten similitudes político-ideológicas en la conformación de proyectos regionales de segunda y tercera "olas", comparten algunas convergencias coyunturales y estructurales para explicar los contextos de crisis del regionalismo sudamericano, a pesar de que las tendencias de fragmentación y desintegración son dispares entre los bloques.
\end{abstract}

Palabras clave: Alba; CAN; Mercosur; América del Sur; Unarsur.

JEL: F02; F15; F50.

DOl: http://dx.doi.org/10.38116/rtm23art3

Data de envio do artigo: 30/4/2020; Data de aceite: 11/8/2020.

\section{INTRODUÇÃO}

A temática do regionalismo internacional adquiriu crescente relevância no mundo desde o pós-Segunda Guerra Mundial, em razão da difusão de diferentes "ondas" de regionalismo em todos os continentes, os quais foram responsáveis pela rápida proliferação de acordos regionais, com distintas naturezas temáticas, níveis de compromisso e estruturas institucionais de negociação.

No contexto da América Latina, essas três ondas também se manifestaram pela emergência de diferentes acordos regionais, inicialmente sob a influência desenvolvimentista de uma política de substituiçáo de importaçóes, por meio de um padráo de regionalismo fechado entre as décadas de 1950 e 1970, passando para um padrão de regionalismo aberto a partir das décadas de 1990 e 2000, sob a influência neoliberal, até chegar a um padrão de regionalismo pós-liberal, sob a influência de uma nova esquerda-neodesenvolvimentista entre as décadas de 2000 e 2010.

Tomando como referência essa trajetória evolutiva do contexto latino-americano, o objetivo geral deste artigo é discutir os processos de regionalismo internacional na América do Sul à luz do atual contexto de crise institucional nos acordos regionais da terceira onda, iniciada neste século - União de Naçóes Sul-Americanas (Unasul) e Aliança Bolivariana para os Povos da Nossa América (Alba) -, da segunda onda de acordos regionais, que vigorou entre a segunda metade dos anos 1980 e a década 
de 1990 - Mercado Comum do Sul Mercosul -, e da primeira onda - Pacto Andino, renomeado e reconfigurado na segunda onda como Comunidade Andina de Nações (CAN) -, a qual compreendeu dos anos 1950 aos 1970.

A tese de trabalho desta pesquisa fundamenta-se na compreensão de que os processos institucionais de macrorregionalização internacional na América do Sul são caracterizados por uma complexidade aberta e latente, fruto de um volátil campo de poder permeado por distintas açóes ao longo do tempo, majoritariamente de natureza política e econômica, as quais se manifestam por dinâmicas processuais fluidas, resultando, assim, em tendências conjunturais de integração, fragmentação e eventual desintegração regional.

A justificativa para o desenvolvimento desta pesquisa fundamenta-se na empírica crise do regionalismo internacional, manifestada por distintos processos de fragmentação e desintegração regional no mundo, razão pela qual o artigo vem corroborar cientificamente para a análise crítica das razóes da crise institucional dos esquemas regionais na sub-região América do Sul, dando continuidade a trabalhos prévios escritos pelos autores. Ilustrada na forma de um questionamento assertivo, a problemática procura compreender se a atual crise dos esquemas regionais na América do Sul possui razóes conjunturais e estruturais, bem como se existem explicaçóes genéricas de convergência, ou específicas, de modo diferenciado entre as iniciativas.

$\mathrm{O}$ fundamento metodológico da pesquisa caracteriza-se por uma natureza exploratória, descritiva e explicativa quanto aos fins e qualitativa quantitativa quanto aos meios, utilizando-se de um método histórico-dedutivo, cujos procedimentos metodológicos de levantamento de dados foram de revisão bibliográfica e documental vis-à-vis os procedimentos de análise de dados com base em hermenêutica internacionalista (economia política internacional e relaçóes internacionais) e análise gráfica.

Estruturado em duas seçôes, além desta introdução e das considerações finais, o artigo possui uma construção com base em uma lógica analítico-discursiva de gradação crescente, que parte de marcos teórico-conceituais sobre a dinâmica regional internacional para realizar uma análise detalhada sobre a crise do regionalismo sul-americano. Ao final, são examinados quatro estudos de caso dos mais importantes projetos regionais da América do Sul.

\section{TENSÕES NO CAMPO DE PODER DA DINÂMICA REGIONAL INTERNACIONAL}

Mais além dasfragmentações ideológicas e materiais dos processos de regionalização transnacional, Söderbaum (2013) explora a crise existente nos próprios estudos sobre regióes e regionalismos, os quais manifestam ou são influenciados por debates caracterizados por uma concepção ideal projetada sobre o papel dos 
blocos regionais com base em uma genérica ultravalorização do modelo europeu de integração ou em específicos paroquialismos de supostas experiências regionais suis generis.

Historicamente, as regióes e o regionalismo internacionais têm sido analisados desde o pós-Segunda Guerra Mundial, tradicionalmente pela manutenção de uma concepção enviesada na linguagem, na medida em que projeta em suas discussões o conceito ideal de integração regional, legado pelos estudos iniciais de natureza liberal-funcionalista sobre os processos de regionalização transnacional, sem necessariamente focar o processo de regionalização transnacional, que é naturalmente permeado por dinâmicas de integração, fragmentação e desintegração (Gänzle, Leruth e Trondal, 2019).

A despeito de as regióes e os regionalismos transnacionais terem adquirido ampla relevância ao longo do tempo, em razão tanto da evolução quantitativa de novos acordos regionais quanto da diversificaçấo qualitativa de diferentes esquemas regionais com conteúdos institucionais políticos, econômicos, securitários e ambientais, muito pouco se avançou nas análises interpretativas e prescritivas do campo científico, com a replicação de discursos Estado-centristas sobre integração regional que não incorporam a complexa realidade das regiôes transnacionais e das açóes regionalistas em termos transescalares e permeados por uma multiplicidade de stakeholders.

O termo regiấo comporta diferentes significados nas relaçôes internacionais, podendo exprimir o enfoque estático de áreas espaciais homogêneas ou heterogêneas de contiguidade continental, ou, ainda o enfoque dinâmico, seja de espaços intranacionais de conglomeração onde são projetadas redes internacionais de produção integrada, seja de macroconcepçôes espaciais onde são institucionalizados blocos regionais e complexos regionais de segurança (Senhoras, 2015, p. 413).

De fato, a multiplicidade dos espaços regionais internacionais demonstra uma elasticidade espacial que parte de microrregióes subnacionais de conglomeração para a projeçâo de vetores de paradiplomacia, como de clusters e arranjos produtivos, e alcança macrorregiōes nas quais diferentes estratégias diplomáticas de regionalismo fechado ou aberto engendram dinâmicas específicas de institucionalidade nos acordos regionais (Senhoras, 2013a; 2015).

A complexa realidade das regiōes internacionais, a despeito de não ter tradicionalmente merecido a devida fundamentação conceitual ao longo dos anos pela comunidade científica especializada, com o recorrente uso de jargóes técnicos imprecisos ou de uso vulgar, merece minimamente ser apreendida a partir oito marcos conceituais regionais que se articulam entre si.

Conforme o quadro 1 , observa-se que os marcos conceituais regionais partem de uma escala analítica elástica (região internacional), passando pela compreensão 
da natureza das açóes políticas (regionalismo) e pela representação da manifestação institucional dos acordos (blocos regionais), para, assim, manifestarem compromissos rasos (cooperação regional) ou profundos (integração regional) em temáticas específicas, embora com eventuais repercussôes negativas em termos conjunturais (fragmentação regional) ou estruturais (desintegração regional).

QUADRO 1

Marcos conceituais regionais

\begin{tabular}{|c|c|}
\hline Região internacional & $\begin{array}{l}\text { Mesoescala extremamente elástica de agregação da espacialidade, podendo ser qualquer } \\
\text { área geográfica em que houver um recorte temático ou uma unidade distinta em virtude de } \\
\text { determinadas características, pois se baseia em variáveis de similitude e semelhança que se } \\
\text { manifestam em macrorregiôes e microrregiões. }\end{array}$ \\
\hline Regionalismo & $\begin{array}{l}\text { Exprime a natureza política presente na manifestação espacial de uma região, sendo considerada } \\
\text { toda ação ou negociação voluntária compartilhada com o objetivo fundamental de promover } \\
\text { acordos de cooperação e/ou integração regional. }\end{array}$ \\
\hline Bloco regional & $\begin{array}{l}\text { Representa a manifestação institucionalizada de acordos interestatais que visam à promoção } \\
\text { de interesses nacionais compartilhados dentro de uma agenda de cooperação e/ou integração } \\
\text { regional de natureza intergovernamental ou supragovernamental. }\end{array}$ \\
\hline Cooperação regional & $\begin{array}{l}\text { Compreende toda a agenda de colaboração específica entre distintos países ou atores } \\
\text { descentralizados de uma região internacional, com o objetivo de avançar em interesses comuns, } \\
\text { respeitados os princípios de voluntarismo, conveniência e flexibilidade. }\end{array}$ \\
\hline Integração regional & $\begin{array}{l}\text { Corresponde a uma estratégia institucional formalizada e compartilhada entre Estados nacionais } \\
\text { e/ou atores descentralizados, com o objetivo de se avançar em interesses comuns segundo um } \\
\text { formato de integração profunda de ações, recursos e compromissos de longo prazo. }\end{array}$ \\
\hline Fragmentação regional & $\begin{array}{l}\text { Representa toda dimensão conjuntural ex post de materialização das agendas ex ante de } \\
\text { cooperação e/ou integração regional, cujo resultado se caracteriza por efeitos negativos colaterais } \\
\text { ou indesejáveis em relação àqueles previamente planejados. }\end{array}$ \\
\hline Desintegração regional & $\begin{array}{l}\text { Compreende todo o processo de desmonte estrutural de dinâmica regional, caracterizando-se como } \\
\text { o estágio último de crise de acordos de cooperação e/ou integração regional, determinando o } \\
\text { eventual fim ou marginalização da dinâmica regional. }\end{array}$ \\
\hline Regionalização internacional & $\begin{array}{l}\text { Caracteriza-se como o fenômeno relacional que materializa os tensionamentos da construção } \\
\text { de um campo processual permeado por vetores de cooperação e integração regional vis-à-vis os } \\
\text { vetores de fragmentação ou mesmo de desintegração regional. }\end{array}$ \\
\hline
\end{tabular}

Fonte: Senhoras e Vitte (2007); Pinto (2015); Gänzle, Leruth e Trondal (2019).

Elaboração dos autores.

A combinação desses conceitos regionais é relevante para demonstrar que a regionalização internacional ou transnacional é, antes de mais nada, um processo relacional dinâmico e suscetível a um complexo campo de poder nas relaçôes internacionais, o qual é permeado por açóes diplomáticas e paradiplomáticas, evoluçóes e involuções, avanços e recuos, apoios e contestações, os quais resultam, em última instância, na conjugação dinâmica de resultados empíricos de integração, fragmentação ou desintegração regional.

Com base nesses marcos conceituais, é possível que os processos de macrorregionalização internacional gerem repercussões de integração regional de juri. Nem sempre, porém, ao longo da evolução do regionalismo internacional no globo ao longo de três grandes ondas (Carvalho, 2018a; Senhoras, 2015), 
houve uma contínua convergência para a materialização da integração regional de facto, em função dos naturais conflitos de negociação intergovernamental ou supragovernamental, os quais podem eventualmente impactar trajetórias negativas em termos institucionais para os blocos regionais, dando ressonância a eventuais conjunturais fragmentaçôes ou mesmo estruturais desintegraçôes regionais (Riggirozzi e Wylde, 2018).

Por um lado, como fenômeno centrípeto, o macrorregionalismo internacional é normalmente dirigido por forças políticas e econômicas que têm o objetivo de uma integração mútua dos países e dos atores subnacionais motivados dentro de temas específicos, como comércio, finanças, infraestrutura, energia, agendas sociais (de educação e saúde, segurança, ou quaisquer outras) (Senhoras e Vitte, 2007), resultando em uma situação de ampla difusão de acordos regionais no mundo como estratégia para a inserção internacional.

Por outro lado, porém, nem sempre a capacidade do campo gravitacional de um bloco regional é suficiente para continuar a atrair os interesses de seus membros ao longo do tempo, dando fundamentação para esvaziamentos em função do surgimento de um complexo emaranhado de acordos paralelos ou sobrepostos entre seus membros, apontado na literatura como um spaghetti bowl (Senhoras, 2010a), em que se identifica a participação simultânea em outros acordos regionais ou mesmo acordos preferenciais de comércio bilaterais, plurilaterais ou inter-regionais (Carvalho, 2018b).

Embora a noção política do regionalismo internacional tenha sido tradicionalmente comandada poranálises descritivas ou pordiscursos prescritivos com base nos marcos conceituais de integração regional, fundamentada por sua evolução nas três grandes ondas, apenas na década de 2000 começaram incrementalmente a surgir discussóes críticas abordando os processos de fragmentação regional em função de determinadas crises regionais, destacando-se o caso da União Europeia, que sistematicamente foi projetado como um modelo internacional.

Partindo da compreensão de que a dinâmica regional internacional é caracterizada como um campo de poder no qual existem diferentes forças atuantes em termos de fortalecimento de uma integração regional profunda ou de esvaziamento por meio de tendências de fragmentação conjuntural ou desintegração estrutural, o texto aborda, na última seção, o contexto sul-americano, a fim de demonstrar criticamente a crise regional existente na Unasul, na Alba, no Mercosul e na CAN.

\section{INTEGRAÇÃO, FRAGMENTAÇÃO E DESINTEGRAÇÃO REGIONAL NA AMÉRICA DO SUL}

No início do século XXI, a etapa mais recente de regionalismo que se desenvolveu na América do Sul se caracterizou por importantes inovaçóes institucionais e 
estratégias regionais. A ascensão de vários governos progressistas no início dos anos 2000 implicou a sua busca por superar a ideologia neoliberal quando assumiram mandatos executivos nos seguintes países: Venezuela (1998), Brasil (2002), Argentina (2003), Uruguai (2004), Bolívia (2005), Equador (2006), Paraguai (2008) e Peru (2011). Em comum, essas lideranças percebiam as consequências da globalização de forma pessimista em temas relacionados ao desenvolvimento e às clivagens entre os hemisférios Norte e Sul (Veiga e Ríos, 2007). Ou seja, esses governos questionaram a ordem internacional assimétrica na qual os países desenvolvidos e as potências mundiais tradicionais buscavam consolidar seu poder por meio de tratados e da difusão de ideologias que lhes eram favoráveis e pelas estruturas de governança global através das quais almejavam preservar o seu status quo (Acharya, 2017).

Portanto, nessa recente onda regional, o foco das políticas dos países da América do Sul se afastou da economia e do comércio ao criticar as reformas neoliberais adotadas entre o fim dos anos 1980 e nos anos 1990 na regiáo (Lima, 2008; Malamud, 2013). Por conseguinte, o regionalismo foi amplamente interpretado como um instrumento de reaçáo a elas. No caso do México, país que desde o final da década 1980 havia optado por abrir seu mercado aos bens e ao capital estrangeiros e se tornar membro do Acordo de Livre Comércio da América do Norte (North American Free Trade Agreement - Nafta). O México é membro do Nafta desde 1994, manteve sua trajetória em matéria de integração regional contrastante com a dos outros países latino-americanos, ratificando-a e aprofundando-a e mantendo sua economia primordialmente voltada para os Estados Unidos (Puchet, Moreno-Brid e Napoles, 2011).

Dessa forma, o regionalismo sul-americano do início do século XXI se voltou à cooperaçáo e ao diálogo político (Sanahuja, 2017), procurando revitalizar a capacidade de açáo coletiva e a soberania dos países da região. A estrutura de governança regional construída teve como resultado um mosaico de acordos, políticas, instituiçóes, identidades e formas de cooperação e concorrência, uma vez que a sub-regiáo experimentou um intenso ativismo regional. Em grande medida, o regionalismo sul-americano decorreu da proeminência de novas ideias de um modelo de desenvolvimento econômico e social proposto como alternativo ao dos anos 1990, pautado pelo retorno da coordenação econômica estatal e pela perspectiva desenvolvimentista ajustada às restriçóes do capitalismo globalizado (Lima, 2008), pela cidadania e pela legitimidade social (Sanahuja, 2017).

O objetivo da maioria dos governos da América do Sul era fortalecer a regiáo como espaço geopolítico, não apenas geoeconômico, como havia acontecido anteriormente, quando houve certa homogeneização das experiências nacionais dos países latino-americanos (Lima, 2014). Para isso, os líderes políticos também 
reviram as suas estratégias de política externa (Serbin, Vigevani e Hershberg, 2014), tendo em vista as mudanças globais em curso: a configuração de um sistema multipolar com a ascensão de novas potências e sua aspiração de construir uma nova ordem mundial (Bizzozero, 2011). Em certa medida, é possível dizer que foi lançada a ideia de construção de um novo consenso na América do Sul, o Consenso de Buenos Aires, em contrapartida ao Consenso de Washington (Bianculli, 2018) e ao projeto norte-americano de formação de uma Alca, lançado em 1994.

Os novos esquemas regionais e as inovaçóes institucionais envolveram a cooperação setorial de áreas como infraestrutura, energia, saúde, segurança, defesa, bem como o diálogo político e a gestão de crises. Essas iniciativas procuraram garantir a provisão de bens públicos regionais, como democracia e direitos humanos, e alcançar metas relacionadas à erradicação da pobreza, à redistribuição de renda e ao provimento de serviços sociais, a fim de garantir maior autonomia em relaçáo às forças de mercado, à política externa dos Estados Unidos e aos demais atores hegemônicos (Riggirozzi e Tussie, 2012).

Em sintonia com essas mudanças, a expansão do Mercosul foi marcada pela entrada da Venezuela como membro pleno do bloco, cujo processo de ratificação pelos Estados-partes terminou em 2012. A Bolívia teve o seu processo de adesão ao bloco mercosulino findado em 2017, com quatro anos para se adequar às suas regras e normas. Com a Guiana e o Suriname foram assinados acordos-quadros de associação em 2013. Além do seu alargamento, o Mercosul buscou a integração voltada para a complementação produtiva e a criação de instituiçóes para compensar e/ou diminuir as desigualdades entre os países-membros do bloco (Botto, 2015). Neste sentido, o Fundo para a Convergência Estrutural do Mercosul (Focem) foi concebido em 2004 com o objetivo de financiar programas destinados a reduzir as assimetrias socioeconômicas dos parceiros menores e menos desenvolvidos em relação aos maiores e mais desenvolvidos, devendo ser um passo imprescindível para responder à diversidade territorial e econômica entre os membros do bloco. A inclusão de temas sociais na agenda de negociaçóes do Mercosul também se tornou um traço dessa nova fase: o Mercosul Social procurou conferir maior aproximação com a sociedade civil, criando mecanismos para ampliar a participação e a coordenação dos parceiros em temas como direitos humanos, meio ambiente, previdência, saúde, cultura, educação, combate à pobreza e à exclusão social. Para seus membros, era clara a ideia de que o comércio era insuficiente para promover a integração regional.

Desde 2007, o bloco mercosulino passou a contar com o Parlamento do Mercosul (Parlasul), criado um ano antes, com o objetivo de estabelecer regras, procedimentos decisórios e atividades que condicionassem o comportamento 
de seus participantes no âmbito regional. A experiência europeia serviu como parâmetro para a proposta do Parlasul porque era a mais avançada e conhecida, mas houve o reconhecimento dos países sul-americanos de que os contextos e as características de cada processo deveriam ser levados em conta na formulação da sua proposta, a fim de se conseguir maior interação com a sociedade. Além disso, pensava-se que a institucionalização do Poder Legislativo poderia resultar na sua maior facilidade de aprofundamento do processo de integração, diminuindo a dependência da vontade política governamental e dos interesses imediatos (Mariano, 2015, p. 127) de cada nação. Mesmo sem ter sido criado como uma instituição supranacional, como o Parlamento Europeu, o Parlasul foi resultado da intenção compartilhada dos membros do Mercosul de ter uma instituição que representasse os interesses dos cidadãos extranacionalmente.

O compromisso com a democracia também foi uma preocupação que levou à consolidação de novas condicionalidades de caráter mais dissuasivo no Mercosul. O Protocolo de Montevidéu, concluído em 2011, reafirmou o conteúdo do Protocolo de Ushuaia, de 1998, e incluiu o art. 1, o qual deveria ser instituído não somente em caso de ruptura democrática, mas também na ocasião de ameaça de ruptura e violação da ordem constitucional - ou de qualquer outra situação que colocasse em risco o exercício legítimo de poder e dos valores e princípios democráticos. Chamado de Protocolo Ushuaia II, ele expandiu os casos nos quais a cláusula democrática do Mercosul poderia ser implementada (Hoffmann, 2016).

$\mathrm{Na}$ área comercial, o Mercosul diversificou parcerias extrarregionais, firmando acordos de livre comércio com alguns parceiros, como Índia (2004), União Aduaneira da África Austral (2008), Israel (2007), Palestina (2008) e Egito (2010), além de firmar acordos de complementação econômica com vizinhos: Colômbia e Equador (2004) e Peru (2010). As negociações do acordo de livre comércio do Mercosul com a União Europeia para a conformação e uma área de livre comércio, as mais antigas em processo de barganha, iniciadas em 1999, evidenciaram uma postura muito mais resistente do bloco sul-americano em aceitar o acordo de temas considerados sensíveis (Veiga e Ríos, 2007), tanto que, a despeito da forte pressão europeia, o acordo não foi concluído após quase duas décadas. Essa atitude também se refletiu nas coalizóes de maior poder político dos países do Sul Global na Organização Mundial do Comércio (OMC) que já havia sido externalizada na negativa final de diversos países sul-americanos à Alca, em 2005. De toda forma, ficou claro aos países desenvolvidos que os países do Sul Global não cederiam mais táo facilmente como nas negociaçóes comerciais de antigas coalizóes de países subdesenvolvidos.

A Alba, instituída em 2004, foi uma das primeiras iniciativas que caracterizaram a nova dinâmica geopolítica da região. Impulsionada pelos então 
presidentes da Venezuela, Hugo Chávez, e de Cuba, Fidel Castro, seu projeto teve caráter anti-hegemônico e forte viés ideológico. Em seu discurso, ficava explícita a abordagem de desenvolvimento no espectro das relaçóes exteriores de seus membros no processo regionalista, no qual o Estado deveria agir contra as forças de mercado e o modelo de "regionalismo aberto", uma vez que o neoliberalismo era interpretado como uma expressão máxima de ameaça imperialista e/ou de intervenção estrangeira (Sanahuja, 2017). Criada como uma organização para pensar alternativas para a sub-regiăo, a Alba procurou indicar maneiras de reduzir assimetrias por meio de projetos que oferecessem benefícios mútuos às economias-membro.

Assim como a Alba, a constituição da Unasul, em 2008, em substituição à Comunidade Sul-Americana de Nações (CSN), lançada com a Declaração de Cusco de 2005, foi o resultado da estratégia de contenção da influência dos Estados Unidos na região, uma grande inovação regional, sinal de "retorno da política" às relaçôes exteriores e à política de desenvolvimento (Sanahuja, 2012). Até aquele momento, a América do Sul ainda não contava com uma organização que abrangesse os doze Estados da regiáo e que fosse um fórum privilegiado para discussão e mediação dos problemas regionais (Lima, 2013). Assim, como mais um espaço para o diálogo político (Nolte e Comini, 2016), a Unasul nasceu especificamente voltada à promoção do desenvolvimento e de uma identidade política e mais diretamente preocupada com o estado da democracia na regiáo, vinculando esforços na formulação de políticas baseadas em direitos relacionados às necessidades dos cidadãos mais vulneráveis da América do Sul (Riggirozzi e Grugel, 2015). A organização, de caráter estritamente intergovernamental (Saraiva, 2010), reconheceu a pluralidade dos modelos econômicos, políticos e institucionais da sub-região, além de suas diversas conformaçôes culturais, étnicas e linguísticas, abrindo a possibilidade de uma arquitetura institucional de geometria variável (Nolte e Comini, 2016).

No âmbito da Unasul, foram criados importantes órgãos para tratar da cooperação em diferentes áreas, a exemplo do Conselho de Defesa Sul-Americano (CDS), uma iniciativa de contestação da participação dos Estados Unidos nos assuntos de defesa regional, que até então havia sido coordenada pela Organização dos Estados Americanos (OEA), claramente liderada pelos Estados Unidos. Em outras palavras, o CDS sinalizou a tentativa e a intenção dos países sul-americanos de promover uma nova arquitetura regional no que se refere às questóes relacionadas à defesa e à segurança, em detrimento daquelas surgidas ainda no período da Guerra Fria, quando os norte-americanos desempenhavam um papel preponderante (Malamud e Schenoni, 2016). Primando pelo diálogo político e pela cooperação em defesa, o CDS foi pensado para permitir aos governantes sul-americanos resolver suas situaçóes de crises de segurança sem 
intervençóes extrarregionais e avançar nas discussóes para formar adiante uma comunidade de segurança regional (Saint-Pierre e Palacios Junior, 2014). Além do CDS, foram institucionalizados, no âmbito da Unasul, os conselhos de saúde, luta contra o narcotráfico, infraestrutura e planejamento, desenvolvimento social, educação, cultura, ciência, tecnologia e inovação.

O projeto do Banco do Sul, lançado em 2007, e que se tornou uma instituição jurídica internacional em dezembro de 2011, foi apresentado como parte do projeto financeiro regional da Venezuela para a América do Sul e como uma alternativa contra-hegemônica às instituições criadas em Bretton Woods no pós-Segunda Guerra e ao Banco Interamericano de Desenvolvimento (BID), com medidas que visavam à "desdolarização" das trocas comerciais e a criação de mecanismos de defesa contra a especulação (Lima, 2013). Tinha como objetivos financiar os eixos de integração física, projetos de desenvolvimento econômico e a redução da pobreza na América do Sul. Para isso, o Banco do Sul deveria conferir maior capacidade de mobilização e alavancagem de recursos, e especialmente agregar os mais diversos tipos de instituiçóes e mecanismos de financiamento com o objetivo de compatibilizar políticas econômicas e de inserção internacional divergentes, estimulando cadeias regionais de valor (Padula, 2011).

Por esse motivo, o Banco do Sul seria o responsável, em um primeiro momento, por dar respaldo à criação do Conselho Sul-Americano de Infraestrutura e Planejamento (Cosiplan), criado em 2009 na III Reunião Ordinária de Chefas e Chefes de Estado e de Governo da Unasul. Aproveitando o capital institucional acumulado em dez anos de experiência da Iniciativa para a Integração da Infraestrutura Regional Sul-Americana (IIRSA), aprovada em 2000, como órgáo técnico, o Cosiplan teria como função conferir um caráter político-estratégico para a infraestrutura na regiáo, agregando o maior número de atores possível (Padula, 2014).

$\mathrm{Na}$ contramáo dos esquemas regionais sul-americanos mais voltados à promoçấo da cooperação, do desenvolvimento e do diálogo político, a Aliança do Pacífico, concebida em 2012, procurou garantir a inserção internacional dos seus membros por meio de acordos comerciais com os Estados Unidos, a União Europeia e outros parceiros comerciais na regiâo Ásia-Pacífico (Sanahuja, 2012; Riggirozzi e Tussie, 2012). Formada por três países sul-americanos (Colômbia, Peru, Chile) mais o México, o objetivo da Aliança do Pacífico, quando lançada, era a construçáo de uma área de livre comércio e de uma plataforma de cooperação política, econômica e comercial que auxiliasse a projeção desses países no plano internacional, sobretudo na Ásia e no Pacífico, regiōes com crescente importância geoeconômica e geopolítica global (Padula, 2014), embora também tenham potencial de fazer um contrapeso político ao Mercosul e/ou à Unasul 
na região. Os membros da Aliança do Pacífico mantinham maior proximidade com os Estados Unidos em relação aos demais dos esquemas sul-americanos anteriormente citados, não só em termos comerciais como também em termos do diálogo político-diplomático (Lima, 2013) e com expectativa de obter benefícios comerciais com o Acordo de Parceria Transpacífico (Trans-Pacific Partnership TPP), concluído em 2015 e liderado, até 2017, pelos Estados Unidos, quando o país decidiu por deixar o acordo.

A piora das condiçôes do cenário externo após a crise econômica internacional de 2008, a tendência de proliferação de acordos comerciais bilaterais ou megarregionais em todo o mundo, o aumento de práticas neoprotecionistas, ou mesmo de fatores domésticos, como a diminuição da demanda internacional por commodities agrícolas e minerais e o desagrado da populaçâo da maioria dos países sul-americanos com as suas condições sociais, além da baixa competitividade de suas economias, moldaram um quadro de mudanças de posição partidária. Em muitos desses países, nos últimos cinco ou seis anos, houve a reversão político-partidária com a eleição de governos de direita e centro-direita, os quais não percebiam a importância dos projetos regionais na América do Sul da mesma forma que seus antecessores ou não concordavam com a maneira como os acordos estavam sendo conduzidos. Diante das mudanças no curso de suas políticas externa, comercial, industrial, de cooperação regional etc., os esquemas entraram em um processo de fragmentação ou desintegração. Os quatro estudos de caso a seguir analisam os mais importantes projetos regionais da América do Sul, destacando suas mudanças recentes no sentido de sua fragmentação e desintegração.

\subsection{Desintegração da Unasul}

Comodiscutido anteriormente, a Unasul surge da ideia compartilhada por governos identificados por uma nova esquerda e pelas agendas do neodesenvolvimento, sendo a Argentina, o Brasil e a Venezuela os pivôs de negociação até chegar a 2008, quando surge institucionalmente o novo bloco dentro de uma agenda pós-liberal ou contra-hegemônica.

A fundamentação para o surgimento deste novo bloco regional baseou-se no fato de que a América do Sul estava embebida por esquemas de regionalismo aberto - CAN e Mercosul - que pouco dialogavam entre si, desfocando uma possível unidade geopolítica e geoeconômica de integração sul-americana (Senhoras, 2010a; 2010b).

Assim como na institucionalização da Unasul, em 2008, a nova esquerda centralizada teve um papel fundamental como catalisadora funcional na estruturação do novo bloco regional, por meio das figuras de Néstor Kirchner, da Argentina, Luiz Inácio Lula da Silva, do Brasil, e Hugo Chávez, da Venezuela 
(Schmidt, 2016; Luigi, 2017) - também estes países tiveram peso decisivo na continuidade e conformação na crise institucional no bloco em 2018, quando mudanças significativas neles ocorreram. Enquanto aquele representa o epicentro para a desconstrução do projeto de integração regional da Unasul, com a suspensáo de seis países, foi em 2019 que houve a saída de três desses países em um contexto de crise fiscal na América do Sul e de emergência de um novo perfil político, com governos de direita que trouxeram outras agendas mais flexíveis nas negociações regionais.

A crise da Unasul se inicia em 2017 e se prolonga em 2018 com a suspensão voluntária de seis membros da uniáo: Argentina, Brasil, Chile, Colômbia, Paraguai e Peru. A pressão para a organização nomear um secretário-geral e o veto de Equador, Venezuela e Suriname ao nome do argentino José Octávio Bordón fizeram com que a Unasul se rompesse em dois blocos distintos. Em agosto do mesmo ano, a Colômbia se retira da organização, seguida pelo Chile e pelo Brasil em 2019 (Egler, 2019, p. 7).

As razôes para uma rápida fragmentação da regionalização transnacional da Unasul fundamentam-se em dinâmicas econômicas e políticas de natureza conjuntural intra e extrarregional vis-à-vis questôes estruturais, relacionadas tanto à latência de um perfil de integraçáo rasa do bloco quanto à conformaçáo de agendas bilaterais e plurilaterais fundamentadas em acordos preferenciais de comércio em um contexto de crise do multilateralismo comercial e de contestação do próprio regionalismo aberto.

Em primeiro lugar, a conjuntural inflexão do pêndulo de poder mundial com a reemergência da direita entre 2014 e 2018 na Europa, nos Estados Unidos e na América do Sul trouxe consigo a reemergência da lógica neoliberal em um contexto de relativa estagnação econômica pós-crise financeira de 2008, a qual se fazia contraposta às iniciativas regionais prévias de natureza pós-liberal ou contra-hegemônica, como a da Unasul (Bragatti e Souza, 2016), ou de natureza comunitarista, como a da União Europeia (Flint e Robinson, 2008).

Em segundo lugar, a volta de uma conjuntural agenda neoprotecionista e de guerras comerciais entre diferentes países, sobretudo entre Estados Unidos e China, fortaleceu a lógica de negociaçóes bilaterais e plurilaterais, a qual eventualmente repercutiu em uma desaceleração do crescimento da economia mundial (Senhoras, 2020) e em uma crescente influência atrativa da Aliança do Pacífico na América do Sul (Pennaforte, 2017), definidora em questionamentos e em crises em vários blocos regionais, sejam consagrados, como o da União Europeia, sejam novos, como o da Unasul.

Em terceiro lugar, uma característica estrutural da Unasul ao longo de uma década fundamenta-se na projeção de uma ampla agenda temática, com discursos 
sociais, políticos, de saúde, infraestrutura, segurança e defesa, porém com um baixíssimo grau de institucionalização, repercutindo, assim, na ausência de uma massa crítica para materializar uma agenda construtiva de projetos de integração de facto, o que pode ser evidenciado pela existência de diferentes conselhos setoriais, mas com pouca expressividade operacional. A sua estruturação ao longo dos anos sempre foi caracterizada, desde 2008, por um grau de baixo compromisso dentro de uma estrutura institucional de negociaçóes intergovernamentais com um elevado número de países, refletindo em um perfil de integração rasa.

Em quarto lugar, a economia internacional tem passado por uma estrutural crise institucional do multilateralismo econômico, na medida em que a Rodada de Doha se encontra relativamente paralisada há quase duas décadas, enquanto as cadeias globais de valor avançam no comércio internacional a partir da consolidação paradiplomática de redes internacionais de produção integrada (Senhoras, 2015), repercutindo em um avanço significativo de acordos comerciais de natureza bilateral e plurilateral, por meio da difusão de acordos preferenciais de comércio que suplementaram, de modo flexível, esforços prévios de regionalismo aberto (Assis, Oliveira e Carvalho, 2018).

De um discurso idealista de integração regional com base em uma lógica nacionalista de negociaçóes intergovernamentais, a falta de consenso sobre os rumos do bloco fez com que o esvaziamento nacional de uma série de países (Argentina, Brasil, Chile, Colômbia, Paraguai e Peru) se tornasse uma crise institucional ao bloco, o qual, desde então, entrou em um ciclo vicioso de desestruturação, perdendo sua capacidade de operacionalizar os diferentes conselhos e instituiçóes, até chegar a uma situação em que os sítios eletrônicos deixaram de estar disponíveis para acesso público.

A desintegração institucional da Unasul representa um momentum no qual o pêndulo histórico da política muda novamente, com a reemergência da direita neoliberal diante de uma crise da nova esquerda e dos movimentos contra-hegemônicos, demonstrando que as mudanças ideológicas do status quo político importam, pois, assim como foram funcionais para a evolução construtiva da Unasul em 2008, também o foram para a sua desconstrução em 2018.

Desde a sua criação em 2008, a União das Naçóes Sul-Americanas teve o germe de sua crise atual e sua potencial autodestruição. A crise da liderança, juntamente com a falta de consenso sobre os valores comuns que deveriam governar a regiáo, fez com que a organização internacional fracassasse (Nolte e Mijares, 2018, tradução nossa).

Se a lógica do regionalismo contra-hegemônico da Unasul possuía uma proposição regional temática ampla fundamentada na cooperação das áreas de saúde, infraestrutura, política, militar e financeira (Senhoras, 2010b), com base em uma extensa agenda e em um perfil frágil de negociaçóes intergovernamentais, 
a lógica neoliberal, por sua vez, que vem a suplantar os esforços da Unasul, toma como base uma visão ainda flexível de negociações intergovernamentais, mas com uma agenda geoeconômica exclusivamente centralizada no livre comércio por meio Foro para o Progresso e a Integraçáo da América do Sul (Prosul).

Fazendo contraposição ao estado de inércia zumbi da Unasul enquanto bloco pós-liberal ou contra-hegemônico, Chile e Colômbia lideraram a conformação do Prosul em 2009, tornando-o um fórum regional de colaboração entre os países, totalmente flexível e com baixíssimos compromissos, fomentando um recuo nos projetos de integração em detrimento de uma cooperação regional possível dentro de uma agenda liberal (Luigi, 2020) e pouco promissora para evoluir de juri ou de facto. Mais um esquema redundante e complexo de spaghetti bowl das relaçóes internacionais na América do Sul (Veras e Senhoras, 2018), no qual os países estão eventualmente em várias iniciativas, mas, antes de projetar a integração, acabam fomentando a fragmentação regional.

\subsection{Desintegração da Alba}

A Alba surgiu como uma iniciativa regional de diplomacia revolucionária para o contexto latino-americano, tendo como objetivo a difusão do movimento socialista-bolivariano, originado com a ascensão de Chávez ao poder na Venezuela, eleito em 1998, tendo como foco engendrar a difusão de um novo perfil de cooperação e soft power na América do Sul e na América Central e no Caribe.

Como antes explicado, estruturada em etapas de um projeto de regionalizaçáo transnacional, a Alba foi criada inicialmente como um acordo de cooperação social entre Venezuela e Cuba em 2004, passando à conformação de bloco com a adesão da Bolívia, quando é ratificado o Tratado de Comércio dos Povos (TCP) no contexto da aliança, dando origem à Alba-TCP. Logo, a Alba-TCP configura-se empiricamente por meio de um tratado de comércio internacional com base em um arcabouço teórico-ideológico do movimento socialista-bolivariano que prioriza em seu discurso o regionalismo contra-hegemônico (Muhr, 2010; Senhoras, 2013b), fundamentado pela substituição dos marcos econômicos liberais das vantagens comparativas pelos marcos econômico-sociais críticos das vantagens cooperativas, nas áreas de educação, cultura, economia, energia, política, social e militar.

Com o adensamento da inclusão de outros países - Antígua e Barbuda, Dominica, Equador, Nicarágua, São Cristóvão e Névis e São Vicente e Granadinas, que passaram a estar circunscritos à operacional petrodiplomacia venezuelana -, a aliança é rebatizada como Aliança Bolivariana para as Américas em 2009, sendo simplesmente denominada como Alba, como um contraponto solidário e contra-hegemônico aos Estados Unidos na América Latina e no mundo. 
A difusão da chamada Revolução Bolivariana, por meio de recursos oriundos da petrodiplomacia venezuelana, tem propiciado a criação de um projeto contra-hegemônico capitaneado pela Alternativa Bolivariana para as Américas (Alba), uma pièce de résistance da gestão Chávez no tocante aos vínculos internacionais da Venezuela e de parte da América Latina em relação os Estados Unidos e seus aliados no continente (Gama Neto e Senhoras, 2009, p. 24).

Por um lado, a trajetória proativa da integração regional da Alba esteve circunscrita a uma concepção geopolítica proativa da Venezuela para a difusão do movimento socialista-bolivariano, mais comumente denominado "socialismo do século XXI", na América Latina, razão pela qual, em um contexto internacional de aumento do preço das commodities na década de 2000, a petrodiplomacia venezuelana se tornou a pedra de toque no financiamento das açóes regionais.

A evolução institucional da Alba pode ser apreendida a partir de uma definição de massa crítica entre 2004 e 2009, diante de um boom do preço internacional do petróleo (gráfico 1), quando a parceria bilateral de contrapartidas entre a diplomacia médica cubana e a diplomacia energética venezuelana se formou, estendendo, em um segundo momento, a difusão de temas comerciais, sociais e políticos para a Bolívia em 2006 e, a partir de 2009, para outros países, diante da dupla crise que afetou os Estados Unidos em 2007 (mercado imobiliário) e 2008 (bancos de investimento).

\section{GRÁFICO 1}

\section{Evolução do preço internacional do óleo cru}

(Em US\$/barril)

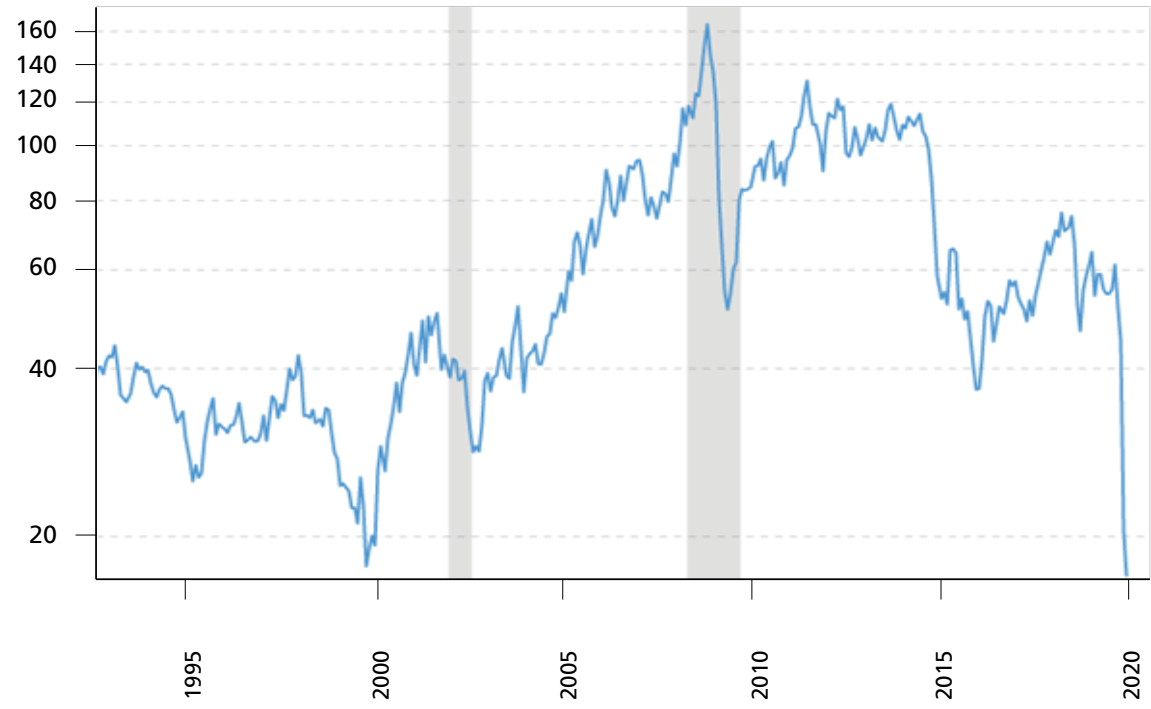

Fonte: Macrotrends, 2020. Disponivel em: <https://www.macrotrends.net/1369/crude-oil-price-history-chart>. Acesso em: 27 abr. 2020. 
Por outro lado, a trajetória inflexiva da fragmentação regional da Alba compartilha suas origens na grave crise econômica e política instaurada na Venezuela, devido ao relativo sincronismo desde a morte do presidente Chávez, em 2013 (Borbón, 2013), e da significativa queda no preço internacional das commodities a partir de 2014 (gráfico 1), mais especificamente do preço do petróleo, responsável por quase $50 \%$ do produto interno bruto (PIB) venezuelano - o que se transformou rapidamente em uma crise política, com uma implosão do movimento socialista-bolivariano.

A gradativa e incremental desintegração do projeto regional contra-hegemônico da Alba naturalmente aconteceu devido à fragilização venezuelana para continuar a alavancagem financeira de uma petrodiplomacia na sua área regional de influência com base na tradicional agenda intervencionista de natureza nacionalista, esquerdista e neopopulista (Senhoras, 2019), conformando uma crise no modelo de financiamento internacional da revolução socialista-bolivariana, o que repercutiu na eventual saída de alguns países do bloco, como o Equador em 2018 e a Bolívia em 2019.

Mais além das dinâmicas conjunturais impactando positivamente a integração ou a fragmentação do projeto regional contra-hegemônico da Alba, o bloco possui, como força profunda de longa duração, a característica estrutural de ter uma alta institucionalidade político-ideológica, porém com um baixo grau de materialidade de sua ampla agenda econômica. Ele demonstra, assim, um forte hiato no projeto regional entre a teoria e a prática, que se manifesta empiricamente em uma fragmentação operacional da iniciativa.

O maior exemplo da fragmentação operacional da Alba pode ser evidenciado pela atividade mais relevante do bloco, a Petro-América (Senhoras, Moreira e Vitte, 2009; Senhoras, 2010c), um projeto de diplomacia energética regional estruturado em três iniciativas sub-regionais de integração energética - Petrosul (países do Mercosul), Petro-Andina (países da CAN) e Petro-Caribe (catorze países da regiáo caribenha) -, porém abandonado ao longo do tempo, sem alcançar qualquer resultado.

A despeito de a evoluçáo da Alba ser caracterizada por um claro ciclo de vida, com fases de desenvolvimento e falência institucional, o bloco regional serviu durante um curto espaço de tempo para difundir uma ideologia socialista-bolivariana e um discurso antiestadunidense com uma relativa significância, já que a Venezuela conseguiu ressonância multilateral no período de alta do preço internacional do petróleo durante a era Chávez (Senhoras, 2014).

No entanto, com a morte de Chávez, a instauração de uma crise econômica derivada da queda internacional do petróleo, o desgaste político dos presidentes Evo Morales, na Bolívia, e Rafael Correa, no Equador, e a própria mudança do pêndulo político no mundo em direção a governos de direita, a Alba passa a 
perder massa crítica, sendo hoje mais um fórum em situação de stand-by que propriamente um espaço regional de integração, persistindo de modo marginal e sem açóes, em função de os países terem buscado adotar soluçóes individualizadas sob o prisma exclusivamente nacional para resolver suas crises internas.

Apesar das afinidades em termos de ideologias e discursos, as trajetórias dos três maiores países da Alba - Venezuela, Equador e Bolívia - foram decisivas para reverter a dinâmica proativa do bloco regional, pois, ao buscar resolver os seus próprios problemas econômicos e políticos nacionais, esses países acabaram por marginalizar a noção solidária, cooperativa e conjunta de um projeto bolivariano (Saint-Upéry e Stefanoni, 2018), repercutindo, dessa forma, em uma falência institucional do bloco, que demonstra a sua fragilidade quando colapsa ao surgirem as primeiras adversidades internacionais.

A compreensão da prevalência de problemas nacionais na desintegração do bloco acontece porque não houve uma crise dos canais de diálogo na Alba, mas apenas uma quebra nos mecanismos de sustentabilidade financeira. Isso demonstrou a baixa maturidade institucional diante de iniciativas regionais como o Mercosul, que passaram a sofrer pressóes externas no mesmo período em função de múltiplos projetos concorrentes de acordos preferenciais de comércio ou de modelos regionais flexíveis, como a Aliança do Pacífico.

Embora outros acordos regionais não tenham impactado negativamente a desestruturação da Alba por meio de efeitos do tipo spaghetti bowl, com eventuais sobreposiçóes e conflitos entre os blocos regionais, seus países-membros, individualmente ou coletivamente, tiveram um papel decisivo no fomento de outros blocos regionais, como o Mercosul e a Unasul, ou na geraçáo de contestações na condição de veto players por meio de declaraçóes oficiais contra acordos regionais liberais, a exemplo da Aliança do Pacífico.

\subsection{Fragmentação do Mercosul}

O Mercosul apresenta um padrão evolutivo caracterizado por uma dinâmica internacional pró-cíclica, na qual em momentos de crescimento internacional existe uma tendência de crescimento dos fluxos comerciais e de investimento intrabloco, em contraposição a momentos de desaceleração do crescimento internacional, quando surge uma correspondente inflexão negativas desses fluxos.

Em razão da característica estrutural de natureza pró-cíclica do Mercosul, a regionalização transnacional do bloco naturalmente apresenta um comportamento pendular, que é identificado por momentos de integração regional, quando há um aumento do comércio regional intrabloco devido à convergência dos ciclos econômicos entre os países, vis-à-vis os momentos de fragmentação regional, 
quando há eventuais desacelerações econômicas ou divergência entre os ciclos econômicos entre os países (Galdioli e Senhoras, 2006).

A evolução pendular do Mercosul manifesta, portanto, fases de maturação da integração regional, em função do aumento dos fluxos comerciais e de investimentos intrabloco, como nos períodos entre 1991 e 1997 e entre 2003 e 2008, em contraposição a fases de crise ou fragmentação regional, a exemplo de 1998 a 2002, em razão de crises financeiras internacionais que atingiram principalmente o Brasil (1999) e a Argentina (2001), repercutindo em divergências nos ciclos econômicos nacionais - assim como entre 2014 e 2016 e a partir de 2020, pela queda internacional do preço das commodities e pela emergência da crise do novo coronavírus, respectivamente, gerando fortes desvalorizações cambiais no bloco (Senhoras, 2020).

GRÁFICO 2

Fluxo de investimentos intrablocos no Mercosul (Em US\$ bilhões)

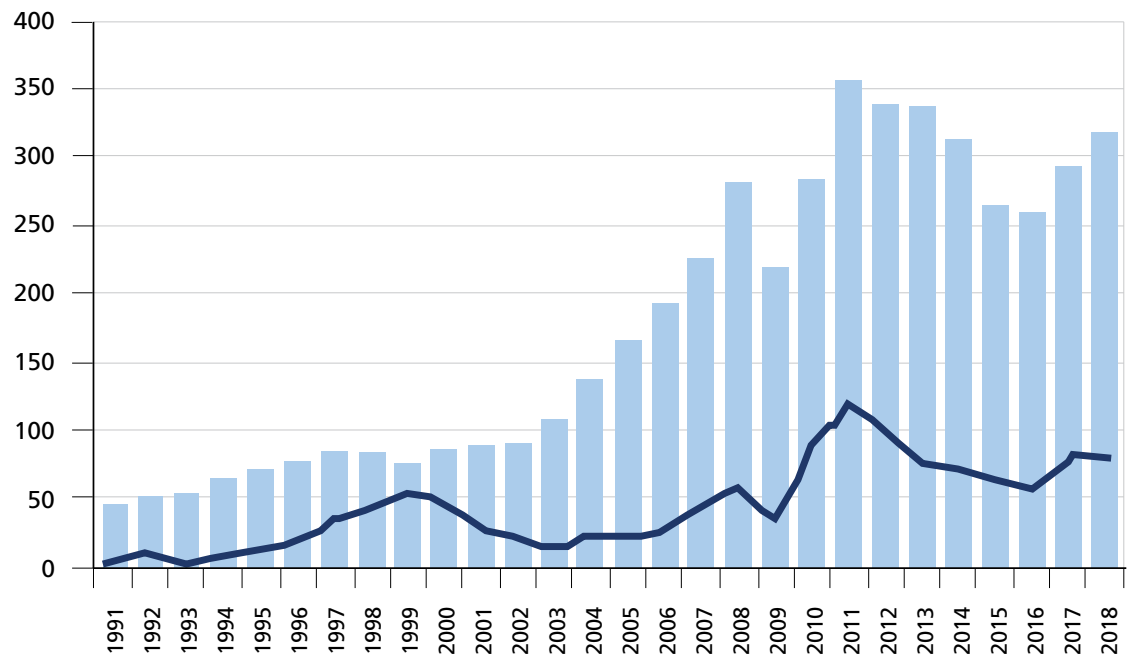

Fonte: United Nations Conference on Trade and Development (Unctad), 2020. Disponível em: <https://unctadstat.unctad.org/> Acesso em: 28 abr. 2020.

Elaboração dos autores.

Diferentemente da CAN, o padrão de fragmentação regional do Mercosul é menos sensível, uma vez que o bloco, desde a sua fundação, possui uma cláusula alfandegária que impossibilita que os países negociem de modo paralelo bilateralmente, razão pela qual há uma forte concentração de fluxos comerciais de exportação e importação intrabloco e, em menor medida, de investimentos que são muito mais voláteis. Esse fato implicou o seguinte: muitos governos de direita e centro-direita eleitos nos últimos quatro anos nos países do Mercosul 
propuseram maior "flexibilização" e abertura do bloco, de modo a negociar tratados de livre comércio com outros parceiros de maneira bilateral. Pautando-se pelo discurso da necessidade de ter maior pragmatismo político, sobretudo no caso de Argentina e Brasil, a flexibilização do Mercosul estaria alinhada aos propósitos da sua agenda econômico-comercial e de política externa, a fim de abrir a economia e diversificar as suas parcerias comerciais extrarregionais, retomando relaçóes com parceiros tradicionais, como União Europeia e Estados Unidos, e estabelecendo novas com países do Sudeste Asiático. No entanto, com a sucessão de governos e mudanças de rota político-partidárias nesses países a partir de 2020, o descompasso ideológico entre as duas maiores economias do bloco afastou novamente os países de trabalhar de modo coordenado em prol dessa ideia.

Os desalinhamentos políticos no bloco mercosulino com relação à Venezuela haviam ficado visíveis alguns anos antes. O imbróglio sobre as condiçóes venezuelanas para assumir a presidência do Mercosul desde a metade de 2016 gerou um desgaste político entre os membros do bloco, culminando com a apresentação da proposta de suspensão do país andino em 2017. Brasil, Argentina e Paraguai mantiveram uma postura crítica com relação ao país, acusando-o de ter interrompido sua ordem democrática, ao passo que o Uruguai não concordou com a suspensáo. Não houve consenso, em grande medida em razão do esvaziamento da liderança regional brasileira na regiâo, que em mais de uma década havia sido determinante para os avanços de esquemas regionais na América do Sul (Carvalho e Gonçalves, 2018). Por um lado, Uruguai e Paraguai voltaram a buscar saídas negociadoras com outros parceiros, e a Bolívia, que era um país associado do Mercosul e assinou o protocolo de adesão ao bloco em 2015, parece sofrer com resistências políticas que atrasam sua condição efetiva de membro. Por outro lado, foi dada continuidade ao processo de aproximação do Mercosul com a Aliança do Pacífico, iniciado mesmo antes da mudança do ciclo político na região (Sanahuja, 2017).

As assimetrias entre as economias permanecem sendo outra característica do Mercosul. O Focem, criado no final de 2004, até então o único instrumento que se concentrava no financiamento de infraestrutura (Bizzozero, 2011), embora de grande importância por seus alcances, continuou não sendo suficiente para superar as grandes diferenças intrarregionais. Recentemente, o Focem tem sido enfraquecido, à medida em que os maiores contribuintes (Brasil e Argentina) tem atrasado os repasses obrigatórios ao fundo, seja por dificuldades econômicas, seja por não entender que ele seja importante agora.

As assimetrias também perduram em outras instâncias. No que se refere ao acordo de livre comércio entre o Mercosul e a União Europeia, finalmente 
assinado no final de 2019, embora ainda em compasso de espera de ratificação por todos os países-membros de ambos os esquemas regionais, são sensíveis as diferenças de resultados que os membros do Mercosul poderão sentir. Além de os termos do acordo parecerem conferir à Uniāo Europeia mais prerrogativas jurídicas de proteçáo ao seu mercado comum sem uma razáo clara, o potencial de exportação, sobretudo de bens agrícolas e agropecuários de Brasil e Argentina, é bem maior que do Uruguai e do Paraguai.

Diante desse contexto, mudanças no plano institucional do bloco se deram em um ritmo lento. No Parlasul, desde 2007, houve dificuldade de estabelecer diálogos em busca da produção de consensos (Mariano, 2011). Em 2019, os países-membros do Mercosul decidiram suspender as eleições diretas dos legisladores do Parlasul a partir do próximo mandato. Com a justificativa de que é necessário aperfeiçoar os mecanismos de integração, os próximos serão eleitos pelos respectivos congressos nacionais. Pelos mesmos motivos, as exceçôes à TEC, as quais historicamente frustraram as metas de uniâo aduaneira perfeita como requisito para concluir o mercado comum, continuam sendo aplicadas, o que não permite que o Mercosul seja mais que uma zona de livre comércio (Peña, 2018). O completo abandono desse objetivo já foi mencionado por governos mercosulinos nacionalistas, os quais consideram as tarifas excessivamente altas e prejudiciais à competitividade dos seus produtos. Há pouco tempo, esse argumento foi mencionado pelo atual governo do Brasil.

Apesar da centralidade econômica na agenda evolutiva do Mercosul, dada a importância das relaçóes comerciais Brasil-Argentina e dos impactos positivos do bloco para a modernização dos setores agropecuário e manufatureiro dos seus membros, ${ }^{3}$ portanto, além dos conjunturais pêndulos econômicos de integração e fragmentação, há também uma pendularidade política que projeta uma ideia de Mercosul, mas que acaba o fragmentando (Senhoras e Vitte, 2006; Almeida, 2006; Hirst, 2002). Isso devido a projetos regionais em que os países do bloco estão envolvidos, que eventualmente repercutem em uma sobreposição regional, como a Unasul, ou à agenda liberal, que apregoa enfoques bilaterais ou plurilaterais, destacando-se negociaçóes com os Estados Unidos e a Aliança do Pacífico (Pennaforte, 2017), esvaziando, dessa forma, os propósitos fundadores do bloco.

\subsection{A continuidade da fragmentação e da desintegração da CAN}

A CAN tem origem na assinatura do Acordo de Cartagena, que constituiu o Pacto Andino em 1969, por Bolívia, Chile, Equador, Colômbia e Peru, com o fim de formar uma união aduaneira. Além do comércio, a intenção dos países dessa sub-região era fortalecer seu poder de barganha e planos de industrialização

3. Disponível em: <http://bit.ly/1Ml9UFK>. Acesso em: 28 abr. 2020. 
coordenada entre seus membros, conferindo um tratamento diferenciado aos países menos desenvolvidos - Bolívia e Equador. Em 1973, a Venezuela se tornou membro do bloco e, anos depois, houve o início da eliminaçáo gradual das tarifas e a negociação da TEC. Os governos acordaram implantar um parlamento regional em 1979, o que se concretizou efetivamente apenas cinco anos depois (em 1984), com a institucionalização do Parlamento Andino (Parlandino) em Bogotá (Mariano, Luciano e Bressan, 2014).

O Chile, no entanto, discordou das medidas liberalizantes, uma vez que o país deu início a reformas neoliberais com a instauração do período ditatorial e decidiu deixar o Pacto Andino em 1976 (Protocolo de Lima), optando por não se tornar membro de nenhum processo de integração regional. Ao longo da mesma década, as dificuldades de os membros aceitarem as determinaçóes para estabelecer a TEC, além do não cumprimento de prazos, acarretou na ideia de parcerias extrarregionais, sobretudo porque sua situação econômica foi agravada pela crise da dívida e por seus efeitos. A frustração dos países menos desenvolvidos com a programação industrial os levou a exigir e obter extensôes repetidas à aplicação do programa de liberalização. Como consequência disso, esse programa acabou sendo suspenso e substituído por um sistema de restriçóes, deixando de lado o programa de industrializaçấo e, por conseguinte, os planos de uniấo aduaneira.

$\mathrm{Na}$ década de 1980, a celebraçấo de acordos comerciais bilaterais complementares foi permitida, o que levou muitos mercados andinos a preferir destinar as suas exportaçốes para fora da sub-regiáo. Até 1995, os membros do pacto haviam firmado 32 tratados de livre comércio (TLCs), os quais tomaram a forma de acordos de complementação econômica (ACEs) (Peñaherrera, 1998), muitos com países desenvolvidos, com os quais o poder de barganha era bastante assimétrico. Esses TLCs tinham regras próprias, ligadas às salvaguardas, e medidas para evitar práticas desleais de comércio, mas eram bastante diferentes entre si.

Esse motivo resultou em uma grande insatisfação para a Venezuela, sobretudo após a eleição de Chávez, em 1998. Em 2006, uma situação se torna o gatilho para a retirada definitiva do país da CAN: foi necessário alterar um artigo (art. 266) para "flexibilizar" suas regras, de modo a aceitar um TLC com os Estados Unidos na área de medicamentos. Convicta de que tal mudança traria danos enormes e irreparáveis à legitimidade das instituiçóes andinas, a Venezuela, politicamente bem mais próxima dos governos de esquerda e centro-esquerda do Mercosul que de alguns países da CAN, apresenta a sua candidatura ao bloco mercosulino no mesmo ano.

Mesmo que o processo de integração estivesse sendo descaracterizado e as economias reformadas, priorizando os possíveis ganhos com a abertura de mercado, nos anos 1990, os membros do pacto sinalizaram sua vontade de 
aprofundar o processo de integração e, em 1996, relançaram o pacto como CAN na lógica de regionalismo aberto do neoestruturalismo cepalino (Hernández, 2011), embora com uma arquitetura institucional mais complexa, similar a um "Estado", com aspiraçóes supranacionais e relacionadas à formação de um mercado comum. Ou seja, a despeito das enormes dificuldades enfrentadas pelo Pacto Andino para cumprir com seus objetivos iniciais, incluindo alcançar uma TEC, o que se deu somente em 1994, a firma do Protocolo de Trujillo, em 1996, concretizou a ideia de uma verdadeira comunidade. Determinou-se um plano ambicioso, que incluiu harmonização gradual de políticas econômicas e sociais e insistiu na necessidade de avançar na TEC, em programas conjuntos de industrialização e de desenvolvimento industrial e agropecuário e de integração física. A ambiciosa institucionalidade, inspirada na Uniâo Europeia, foi conservada (Van Klaveren, 2018).

Com efeito, o comércio intra-CAN evoluiu proporcionalmente mais que o extra-CAN (López, 2010) - entre 1990 e 2007, as exportações intrarregionais aumentaram oito vezes (Sanahuja, 2007) -, a despeito de as exportaçôes dos países andinos continuarem concentradas em bens primários e commodities, e de as importaçóes em bens intermediários e de capital demonstrarem deficiências produtivas estruturais dos países-membros da CAN, as quais repercutiam em deficit comerciais em termos de valores (Cancino, 2015). Além disso, na prática, os objetivos da CAN tiveram enfoque meramente comercial, com baixo conteúdo social e cultural e de identidade regional e pouca complementaridade entre as economias.

Os anos 2000 se caracterizaram por um fator que colocou em evidência ainda mais as diferenças entre os membros da CAN. Após as eleições presidenciais, a CAN ficou assim dividida: de um lado, Colômbia e Peru e, de outro, Bolívia e Equador. Os primeiros continuaram defendendo um modelo de regionalismo aberto, baseado em uma agenda de liberalização econômica, com o intuito de se inserir em uma economia global permeada por TLCs bilaterais e inter-regionais com países terceiros. Esses países foram atraídos pela agressiva diplomacia comercial dos Estados Unidos, após o fracasso definitivo das negociaçóes da Alca, em 2005, além dos amplos recursos norte-americanos destinados a outras áreas, como o narcotráfico, injetados nas economias de Colômbia, Peru e Bolívia desde os anos 1990 no âmbito da estratégia andina. Os segundos, voltados ao regionalismo pós-liberal ou antissistêmico (Coral e Reggiardo, 2016). Isso acabou levando as negociaçôes da CAN a uma situação de marasmo (Briceño-Ruiz, 2013), aprofundando o ceticismo com os compromissos políticos assumidos, mesmo após a "refundação" do bloco, e colocando à prova sua coesáo interna diante das ofertas de grandes e importantes parceiros externos, como Estados Unidos e União Europeia (Sanahuja, 2007; Hernández, 2011). 
O quadro a seguir mostra os TLCs assinados pelos países da CAN desde os anos 1990. É notório que a quantidade aumentou no decorrer dos anos 2000, refletindo a "divisão" da CAN: o número de acordos que envolvem Bolívia e Equador é bem inferior ao firmado por Peru e Colômbia, as maiores economias da sub-região.

QUADRO 2

Número de TLCs dos países-membros da CAN (2020)

\begin{tabular}{|c|c|c|c|}
\hline Membro CAN & Parceiro & Data da assinatura do TLC & Entrada em vigor do TLC \\
\hline \multirow{2}{*}{ Bolívia } & Mercosul & 1996 & 1997 \\
\hline & México & 2010 & 2010 \\
\hline \multirow{12}{*}{ Peru } & Colômbia & 2008 & 2011 \\
\hline & Canadá & 2008 & 2009 \\
\hline & Costa Rica & 2011 & 2013 \\
\hline & Austrália & 2018 & 2020 \\
\hline & China & 2009 & 2010 \\
\hline & Efta & 2010 & 2011 \\
\hline & União Europeia & 2012 & 2013 \\
\hline & Japão & 2011 & 2012 \\
\hline & Coreia do Sul & 2010 & 2011 \\
\hline & Singapura & 2009 & 2009 \\
\hline & Tailândia & 2010 & 2011 \\
\hline & Estados Unidos & 2006 & 2009 \\
\hline \multirow{8}{*}{ Colômbia } & União Europeia & 2012 & 2013 \\
\hline & Costa Rica & 2013 & 2016 \\
\hline & Efta & 2008 & 2011 \\
\hline & México & 1994 & 1995 \\
\hline & Mercosul & 2017 & $2017-2018$ \\
\hline & El Salvador-Guatemala-Honduras & 2007 & $2009-2010$ \\
\hline & Coreia do Sul & 2013 & 2016 \\
\hline & Estados Unidos & 2006 & 2012 \\
\hline Equador & Estados Unidos & 2014 & 2017 \\
\hline
\end{tabular}

Fonte: Organization of American States (OAS) Foreign Trade Information System.

Elaboração dos autores.

Obs.: Efta - European Free Trade Association (Associação Europeia de Comércio Livre).

Ademais, fica explícito, observando os dados, que muitos países asiáticos se tornaram parceiros privilegiados dos países-membros da CAN, contribuindo, assim, para a configuração do spaghetti bowl sul-americano. Da mesma forma que as partes do Mercosul, os países andinos aproveitaram a onda de alta de preços de commodities (2003-2014), alavancada sobretudo pela demanda chinesa, e estabeleceram acordos preferenciais com mercados da Ásia. Também motivados 
pelo grande potencial exportador para as economias asiáticas, e sem deixar sua participação na CAN, Colômbia e Peru se juntaram a México e Chile em 2012 para formar a Aliança do Pacífico. Quando entrou em vigor, em 2015, a aliança evidenciou a crise pela qual a CAN já passava, porque dividiu novamente os membros do bloco entre aqueles que "miravam" o Pacífico e os que olhavam para o Atlântico. Em outras palavras, as diferenças de estratégia no comércio internacional ficam explícitas (Nolte e Wehner, 2015).

Assim como outros países em desenvolvimento, as escolhas dos membros da CAN os tornaram muito mais competidores entre si por potenciais mercados que atores em processo de integraçáo, tanto por trocas comerciais como por investimento externo estrangeiro, aprofundando a fratura da integração regional (Cancino, 2015). O volume exportado para a Ásia manteve tendência de crescimento, mesmo que o mercado intrarregional tivesse um potencial bem maior de ampliar as exportaçôes da sub-região de manufaturas de maior valor agregado. Por esse motivo, a ideia de mercado comum se perdeu e a CAN se manteve como uma uniáo aduaneira imperfeita.

Findado o período de alta dos preços das commodities, houve impactos para as economias andinas. O Equador, por exemplo, é uma economia dolarizada desde 2000 e dependente da produção e da exportaçấo de petróleo e de outros minerais. A desaceleração econômica e a consequente deterioração das condiçóes de vida da populaçáo a partir de 2016 provocaram instabilidade social, culminando com manifestaçóes contra o aumento do preço da gasolina em 2019 e de outros itens de consumo básicos.

Portanto, a CAN entrou em um processo de fragmentação e desintegração bem antes do Mercosul, da Alba e da Unasul. No que tange à fragmentação, os TLCs se proliferaram. No que se refere à integração, os compromissos se perderam. De maneira geral, as instituições não cumpriram com os objetivos do Pacto Andino ou da CAN. A ideia da supranacionalidade não foi colocada em prática e as diferenças políticas e assimetrias econômicas permaneceram, gerando frustrações e sobreposição de acordos.

\section{CONSIDERAÇÕES FINAIS}

Este artigo discutiu elementos que explicam a atual crise do regionalismo na América do Sul, partindo de uma discussáo teórica, que admite que a manifestação de distintos processos de fragmentação e desintegração regional em várias partes do mundo ocorre paralelamente, e que a dinâmica internacional é cada vez mais complexa e náo deixa de ser influenciada por relações de poder, sem necessariamente repercutir processos mais aprofundados de integração regional. Ao contrário, eles podem sofrer reveses, como se fragmentar e até mesmo se 
desintegrar. Após a descrição da evolução nas primeiras décadas do século XXI, explícita com eventos tanto domésticos quanto externos, que resultaram em novas iniciativas e estratégias regionais ou, ainda, em readequaçóes de projetos regionais existentes no escopo do regionalismo de terceira onda, foram examinados quatro estudos de caso de esquemas regionais, considerados os mais importantes da América do Sul, a fim de verificar se os processos de fragmentação e desintegração regional mais recentes se devem a razóes estruturais e conjunturais, e se há fatores particulares ou genéricos para isso.

$\mathrm{Na}$ área econômico-comercial, CAN e Mercosul experimentaram fragmentação e desintegração, embora ambos os blocos regionais tivessem proposto se tornar uma união aduaneira ainda na primeira onda regionalista e, em seguida, evoluir para uma integração mais profunda, alcançando a configuração de um mercado comum. Os países andinos optaram por estabelecer TLCs desde o final dos anos 1980, ainda durante na segunda onda, sem deixar a CAN - desde 2015, Colômbia e Peru também começaram a participar da Aliança do Pacífico. Durante a fase do regionalismo contra-hegemônico, as parcerias extrarregionais da CAN se ampliaram e o projeto de integraçáo não avançou. O Mercosul, por sua vez, utilizou-se dessa estratégia posteriormente. Em grande medida, ela foi postergada em razão do avanço da agenda de natureza mais política e social do que econômica do bloco do Cone Sul durante a fase dos mandatos dos governos de esquerda e centro-esquerda e, assim mesmo, sem o enfoque bilateral, embora preferencial, da mesma forma que a CAN. Portanto, no caso da CAN, fatores estruturais acompanharam a sua fragmentação e desintegração; no Mercosul, as razões foram de natureza essencialmente conjuntural, com ressonância sobre a sua dinâmica. Como consequência disso, as escolhas das duas unióes aduaneiras incompletas e fortemente institucionalizadas sul-americanas se agregam aos acordos comerciais que formam o spaghetti bowl mundial.

Os arranjos regionais de natureza política analisados, a Unasul e a Alba, também foram e estáo sendo remodelados em função das modificaçóes no pêndulo político-partidário nacional e das consequências de crises econômicas. A Alba ficou bastante enfraquecida com o falecimento de Chávez e a queda do preço do petróleo nos últimos anos, além da instabilidade política vivenciada na Bolívia e no Equador. Sem dúvida, o enfraquecimento da ideologia contra-hegemônica teve um papel significativo para esse esquema regional, sobretudo quando se contrapóem seus avanços aos seus propósitos apresentados em 2004. Assim também acontece na Unasul. Mais uma vez, a lógica neoliberal suplanta os esforços dessa instituiçáo regional, principalmente em razáo dos desalinhamentos políticos de seus membros relativos à Venezuela. A despeito de alguns esforços de continuidade e dos avanços na Unasul, seu esvaziamento e, no limite, sua desintegração parecem inevitáveis. Como em outras ocasiōes, a saída dos países 
sul-americanos a crises, desentendimentos e desalinhamentos políticos se dá por meio da criação de um novo arranjo regional, o Prosul, no âmbito político, e de acordos de livre comércio no plano comercial.

\section{REFERÊNCIAS}

ACHARYA, A. After liberal hegemony: the advent of a multiplex world order. Ethics and International Affairs, v. 31, n. 3, p. 271-285, 2017.

ALMEIDA, P. R. América do Sul: rumo à desintegração política e à fragmentação econômica? Carta Internacional, jul. 2006.

ASSIS, B. F. N.; OLIVEIRA, K. M. S.; CARVALHO, P. N. O regime multilateral de comércio internacional: crise e acordos preferenciais de comércio. Conjuntura Global, v. 7, n. 1, p. 36-54, 2018.

BIANCULLI, A. Latin America and the study of regions: from international political economy to comparative regionalism and back? In: FLACSO-ISA JOINT INTERNATIONAL CONFERENCE, 2018, Quito. Proceedings... Quito: Flacso-ISA, 2018.

BIZZOZERO, L. América Latina a inicios de la segunda década del siglo XXI: entre el regionalismo estratégico y la regionalización fragmentada. Revista Brasileira de Política Internacional, v. 54, n. 1, p. 29-43, 2011.

BORBÓN, J. A. Alba en su ciclo más bajo desde su conformación. Cuadernos sobre Relaciones Internacionales, Regionalismo y Desarrollo, v. 8, n. 16, 2013.

BOTTO, M. América Latina y la integración regional: ¿quo vadis? Del Mercosur a la Unasur: un análisis sobre los alcances de la cooperación regional. Confines, v. 11, p. 9-38, 2015.

BRAGATTI, M. C.; SOUZA, N. A. Unasul: iniciativa de integração regional? Instituição de regionalismo pós-liberal ou contra-hegemônico? Concertación ou coordenaçáa de interesses comuns? (os debates conceituais sobre um processo em construção). Conjuntura Austral, v. 7, n. 35, p. 43-51, 2016.

BRICEÑO-RUIZ, J. B. La Alianza del Pacífico: la viabilidad de un naciente bloque regional. In: ARDILA, M. (Org.). El Pacífico latinoamericano y su inserción internacional. Bogotá: Pontificia Universidad Javeriana, 2012. p. 139-142.

CANCINO, A. R. La integración en energía eléctrica entre los países de la comunidad andina: análisis, obstáculos y desafíos. Tempo do Mundo, v. 1, n. 2, p. 7-45, jul. 2015. 
CARVALHO, P. N. Entre o multilateralismo, o regionalismo e o bilateralismo: notas para pensar a estratégia brasileira nas negociações de acordos preferenciais de comércio e investimentos. In: CONFERÊNCIA SOBRE RELAÇÓES EXTERIORES, 5., 2018, Brasília. Anais... Brasília: FUNAG, 2018a.

. Da institucionalização aos impasses da OMC e a proliferação de acordos preferenciais de comércio no início do século XXI. Brazilian Journal of International Relations, v. 7, n. 2, 2018b.

CARVALHO, P. N.; GONCALVES, F. C. N. I. Reflexôes sobre a atuação do Brasil na América do Sul no século XXI: uma potência regional? Cuadernos de Política Exterior Argentina, v. 127, 2018.

CORAL, M. L.; REGGIARDO, G. La Alianza del Pacífico en el regionalismo sudamericano actual. Revista Mexicana de Política Exterior, n. 106, p. 187-204, ene./abr. 2016.

EGLER, C. A. G. Crise e (des)integração regional na América do Sul. In: ENCONTRO NACIONAL DE PÓS-GRADUAÇÃO E PESQUISA EM GEOGRAFIA, 13., 2019, São Paulo. Anais... São Paulo: USP, 2019.

FLINT, J.; ROBINSON, D. Community cohesion in crisis? New dimensions of diversity and difference. Bristol: Policy Press, 2008.

GALDIOLI, A.; SENHORAS, E. M. Da primeira marcha a marcha ré: prognósticos de uma agenda de integração regional de Brasil e Argentina no Mercosul. Revista INTERthesis, v. 3, n. 2, 2006.

GAMA NETO, R. B.; SENHORAS, E. M. Petróleo como arma de poder: uma contextualização da petrodiplomacia venezuelana nas relaçôes internacionais. Meridiano 47, n. 105, p. 24-26, abr. 2009.

GÄNZLE, S.; LERUTH, B.; TRONDAL, J. Differentiated integration and disintegration in a post-Brexit era. Abingdon: Routledge, 2019.

HERNÁNDEZ, L. H. Porvenir de la Comunidad Andina de Naciones (CAN): 2000-2010. Revista de Investigaciones Unad, v. 10, n. 2, p. 266-283, 2011.

HIRST, M. Mercosul politics: between fragmentation and integration - paths to regional integration. Washington: Woodrow Wilson International Center for Scholars, 2002.

HOFFMANN, A. R. As organizaçóes regionais e a promoção e proteção da democracia: reflexôes a partir das práticas de intervenção democrática na América do Sul. Cadernos CRH, v. 29, n. 3, p. 47-57, 2016.

LIMA, M. R. S. Desempenho de governos progressistas no Cone Sul: agendas alternativas ao neoliberalismo. Rio de Janeiro: Ediçôes Iuperj, 2008. 
Relações interamericanas: a nova agenda sul-americana e o Brasil. Lua Nova, n. 90, p. 167-201, 2013.

.A nova agenda sul-americana e o papel regional do Brasil. In:HERSHBERG, E.; SERBIN, A.; VIGEVANI, T. (Org.). Pensamiento Propio, n. 39, 2014.

LÓPEZ, A. Presentación sobre la CAN en el marco del encuentro de integración productiva e integración social en América del Sur. Bogotá: Hotel JW Marriott, 2010.

LUIGI, R. A integraçáo regional na América do Sul: a efetividade da União das Naçôes Sul-Americanas (Unasul). 2017. Tese (Doutorado) - Universidade Estadual de Campinas, Campinas, 2017.

. Regiáo eintegração regional: oconceitogeográfico ea teoriainternacionalista. In: SENHORAS, E. M.; VITTE, C. C. S.; ROCHA, A. S. (Org.). Geografia e relaçóes internacionais: debates temáticos! Boa Vista: EdUFRR, 2020.

MALAMUD, A. Overlapping regionalism, no integration: conceptual issues and the Latin American experiences. EUI RSCAS, n. 20, 2013.

MALAMUD, A.; SCHENONI, L. Neoliberal institutionalism and neofunctionalism in Latin American security studies. In: MARES, D. R.; KACOWICZ, A. M. (Ed.). Routledge handbook of Latin American security. New York: Routledge, 2015. p. 44-56.

MARIANO, K. L. P. A eleição parlamentar no Mercosul. Revista Brasileira de Política Internacional, v. 54, n. 2, p. 138-157, 2011.

Regionalismo na América do Sul: um novo esquema de análise e a experiência do Mercosul. In: MARIANO, K. L. P. Regionalismo na América do Sul: um novo esquema de análise e a experiência do Mercosul. São Paulo: Editora Unesp; Cultura Acadêmica, 2015.

MARIANO, K. L. P.; LUCIANO, B. T.; BRESSAN, R. N. Parlamento andino: desafios e obstáculos da democratização da integração andina. In: ENCONTRO ANUAL DA ANPOCS, 38., 2014, Caxambu. Anais... Caxambu: Anpocs, 2014.

MUHR, T. Venezuela e Alba: regionalismo contra-hegemônico e ensino superior para todos. Educaçáo e Pesquisa, v. 36, n. 2, p. 1-24, 2010.

NOLTE, D.; COMINI, N. M. Unasur: regional pluralism as a strategic outcome. Contexto Internacional, v. 38, n. 2, p. 545-565, 2016.

NOLTE; D.; MIJARES, V. M. La crisis de Unasur y la deconstrucción de Sudamérica. El Espectador, 24 abr. 2018. Disponível em: <https://www. elespectador.com/noticias/el-mundo/la-crisis-de-unasur-y-la-deconstruccion-desudamerica-articulo-751730>. Acesso em: 24 abr. 2020. 
NOLTE, D.; WEHNER, L. Geopolitics in Latin America: old and new. In: MARES, D. R.; KACOWICS, A. M. (Ed.). Routledge handbook of Latin American security. New York: Routledge, 2015. p. 33-43.

PADULA, R. As visóes dominantes sobre a integração regional. In: COSTA, D. (Org.). América do Sul: integração e infraestrutura. 1. ed. Rio de Janeiro: Capax Dei, 2011. p. 143-208.

. Da IIRSA ao Cosiplan da Unasul: a integração da infraestrutura na América do Sul nos anos 2000 e suas perspectivas de mudança. In: DESIDERÁ NETO, W. A. (Org.). O Brasil e as novas dimensóes da integração regional. Brasília: Ipea, 2014. p. 292-352.

PENAA, F. ¿Una renovación necesaria en la construcción del Mercosul? Posible desarrollo de una nueva etapa en su construcción". Panorámica, 19 nov. 2018. Disponível em: <https://www.panoramical.eu/america-latina-y-caribe/unarenovacion-necesaria-en-la-construccion-del-mercosur-ideas-en-torno-al-posibledesarrollo-de-una-nueva-etapa-en-su-construccion/>. Acesso em: 30 abr. 2020.

PENAAHERRERA, G. S. El grupo andino de hoy: hacia la integración de Sudamérica. Quito: Universidad Andina Simón Bolívar, 1998.

PENNAFORTE, C. P. Brasil, Mercosul e Aliança do Pacífico: convergência ou antagonismo. Boa Vista: Editora UFRR, 2017.

PINTO, J. Entre la integración y la fragmentación regional: el desafío político de nuestro tiempo. Buenos Aires: Eudeba, 2015.

PUCHET, A. M.; MORENO-BRID, J. C.; NAPOLES, P. R. Mexico's regional integration with North America and Latin America: challenges and opportunities. Economía Unam, v. 8, n. 23, p. 3-36, 2011.

RIGGIROZZI, P.; GRUGEL, J. Regional governance and legitimacy in South America: the meaning of Unasur. International Affairs, v. 91, n. 4, p. 781-797, 2015.

RIGGIOROZZI, P.; TUSSIE, D. The rise of post-hegemonic regionalism in Latin America. In: . The rise of post-hegemonic regionalism: the case of Latin America. London: Springer, 2012. p. 167-182.

RIGGIROZZI, P.; WYLDE, C. (Ed.). Handbook of South American governance. Abingdon: Routledge, 2018.

SAINT-PIERRE, H. L.; PALACIOS JUNIOR, A. M. C. As medidas de confiança no Conselho de Defesa Sul-Americano (CDS): análise dos gastos em defesa (2009-2012). Revista Brasileira de Política Internacional, v. 57, n. 1, p. 22-39, 2014.

SAINT-UPÉRY, M.; STEFANONI, P. Bolívar's nightmare: crisis and fragmentation among Alba members' governments. Hérodote, n. 171, 2018. 
SANAHUJA, J. A. Regionalismo e integración en América Latina: balance y perspectivas. Pensamiento Ibero-Americano, n. 0, p. 75-106, feb. 2007.

. Regionalismo post-liberal y multilateralismo en Sudamérica: el caso de Unasur. In: SERBIN, A.; MARTÍNEZ, L.; RAMANZINI JÚNIOR, H. (Org.). Anuario de la integración regional de América Latina y el Gran Caribe. Buenos Aires: Cries, 2012. p. 19-72.

- Regionalismo e integración en América Latina: de la fractura Atlántico-Pacífico a los retos de una globalización en crisis. Pensamiento Propio, n. 44, p. 29-76, 2017.

SARAIVA, M. G. Brazilian foreign policy towards South America during the Lula administration: caught between South America and Mercosur. Revista Brasileira de Política Internacional, v. 53, p.151-168, 2010.

SCHMIDT, R. V. A institucionalizaçáo da Unasul (2004-2012): os papéis de Argentina, Brasil e Venezuela. 2016. Tese (Doutorado) - Universidade Federal do Rio Grande do Sul, Porto Alegre, 2016.

SENHORAS, E. M. A construçáo da América do Sul nas relaçóes internacionais: da fragmentação colonial ao espaço regional transnacional na união sul-americana. Boa Vista: EdUFRR, 2010a.

A regionalização transnacional na América do Sul e a institucionalização diplomática da Unasul. In: CONGRESO LATINOAMERICANO DE CIENCIA POLÍTICA, 5., 2010, Buenos Aires. Anais... Buenos Aires: Alacip, $2010 \mathrm{~b}$.

Uma agenda de estudos sobre a regionalizaçáo transnacional na América do Sul. 2010. Tese (Doutorado) - Universidade Estadual de Campinas, Campinas, 2010c.

Múltiplas camadas das relaçóes internacionais entre a diplomacia e a paradiplomacia. Revista Intellector, v. 9, n. 18, p. 1-14, 2013 a.

O ciclo político de Hugo Chávez no poder e seu impacto na Venezuela. In: PENNAFORTE, C. P.; OLIVEIRA, F. (Org.). A Venezuela em transformaçáo: a era Chávez e a revolução bolivariana. 1. ed. Rio de Janeiro: Cenegri Ediçóes, 2013 b.

Conflito e cooperaçáo no complexo regional de segurança na América do Sul. Boa Vista: EdUFRR, 2014.

A dinâmica regional nas relações internacionais. Conjuntura Global, v. 4, n. 3, 2015.

. Venezuela em rota de colisão: da estabilidade à crise. Roraima em Foco, 1ํ abr. 2019. Disponível em: <https://roraimaemfoco.com/artigo-venezuela-em-rotade-colisao-da-estabilidade-a-crise-eloi-martins-senhoras/>. Acesso em: 27 abr. 2020. 
Novo coronavírus e seus impactos econômicos no mundo. Boletim de Conjuntura (BOCA), v. 1, n. 2, 2020.

SENHORAS, E. M.; MOREIRA, F.; VITTE, C. C. S. A agenda exploratória de recursos naturais na América do Sul: da empiria à teorização geoestratégica de assimetrias nas relaçóes internacionais. In: ENCUENTRO INTERNACIONAL DE GEÓGRAFOS DE AMÉRICA LATINA, 12., 2009, Montevidéu. Anais... Montevidéu: Egal, 2009.

SENHORAS, E. M.; VITTE, C. C. S. Avanços e tropeços do Mercosul: um debate sobre os quinze anos de integração regional. In: JORNADA INTERNACIONAL DE JOVENS PESQUISADORES DA AUGM, 14., 2006, Campinas. Anais... Campinas: Unicamp, 2006.

A escala do regionalismo transnacional sob construçáo. In: ENCUENTRO DE GEÓGRAFOS DE AMÉRICA LATINA, 11., 2007, Bogotá. Anais... Bogotá: Unal, 2007.

SERBIN, A.; VIGEVANI, T.; HERSHBERG, E. La nueva dinámica hemisférica: desafíos y potencialidades. Pensamiento Propio, n. 39, p. 11-34, 2014.

SÖDERBAUM, F. Rethinking regions and regionalism. Georgetown Journal of International Affairs, n. 13, summer/fall, 2013.

VAN KLAVEREN, A. El eterno retorno del regionalismo latino-americano. Nueva Sociedad, n. 275, p. 62-72, mayo/jun. 2018.

VEIGA, P. da M.; RÍOS, S. P. O regionalismo pós-liberal na América do Sul: origens, iniciativas e dilemas. Santiago: Cepal, 2007. (Série Comércio Internacional).

VERAS, N. S.; SENHORAS, E. M. Direito dos migrantes e a Corte Interamericana de Direitos Humanos. Boa Vista: EdUFRR, 2018. 